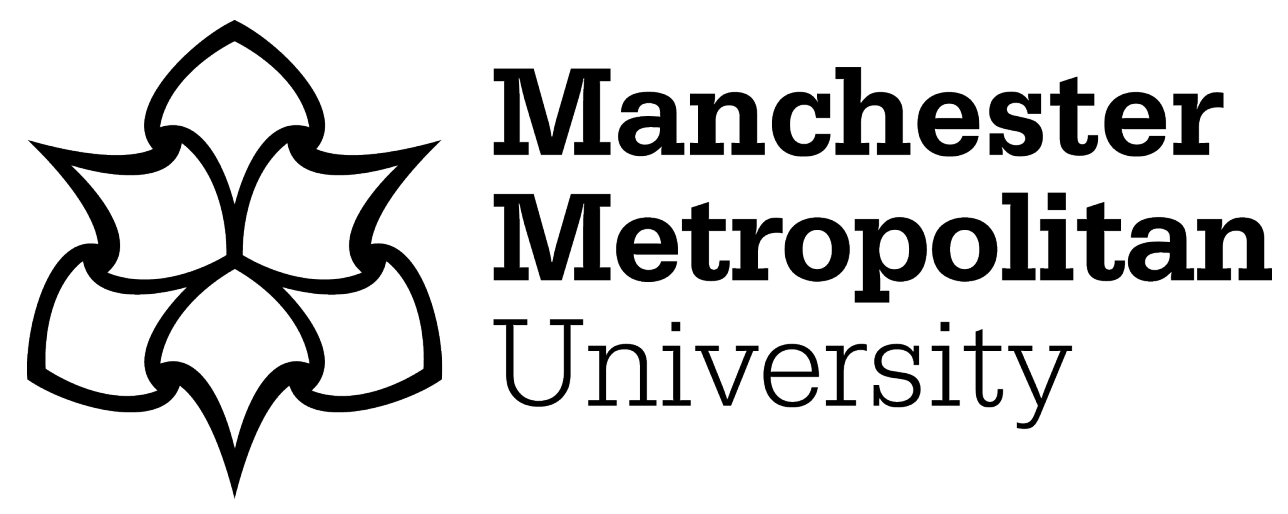

Ivinson, G ORCID logoORCID: https://orcid.org/0000-0002-5552-9601 (2020) The power of living knowledge: re-imagining horizontal knowledge. Asia-Pacific Journal of Teacher Education, 48 (1). pp. 15-29. ISSN 1359866X

Downloaded from: https://e-space.mmu.ac.uk/624677/

Version: Accepted Version

Publisher: Taylor \& Francis (Routledge)

DOI: https://doi.org/10.1080/1359866X.2019.1696453

Please cite the published version 


\title{
The power of living knowledge: re-imagining horizontal knowledge
}

\author{
Gabrielle Ivinson (iD
}

Education and Community, Manchester Metropolitan University, Manchester, UK

\begin{abstract}
Educationalists tend to imagine school curricula organised solely around academic, formal knowledge or horizontal discourse. Yet, despite curricula organised around vertical discourses such as science, geography and mathematics, the working classes, the poor and minority ethnically groups achieve less well in education than the middle classes. The paper aims to re-think horizontal knowledge by paying attention to it as place-based, sensory, embodied, indigenous and historically developed forms of knowing in order: 1) to broaden debates about school knowledge; 2) to support teachers to recognise and legitimate forms of knowing beyond those prescribed by academic curricular and 3) to re-imagine it as living knowledge that has value. To illuminate what might be powerful in horizontal knowledge Gilbert Simondon's genetic ontology and his concepts of pre-individuation, persons are not fixed for all time, and transindividual, a uniquely collective form of knowing, are introduced. The paper argues that by re-thinking horizontal knowledge young people can be imagined as having multiple ways of being and education can support them to become more; more than social class, more than poverty, more than an exam failure and more than an individual, fixed for all time.
\end{abstract}

\section{Introduction}

Educationalists tend to imagine school curricula organised solely around academic, formal knowledge. Debates about curriculum often invoke Bernstein's (1990, 1999, 1996) concepts of vertical and horizontal discourse. The superiority of vertical discourse epitomised by science, in comparison to horizontal discourse, is based on claims about its truth or power (e.g., Young \& Muller, 2013). Powerful knowledge is powerful because it is publicly available in texts and so, the argument goes, can be made available to all irrespective of young people's lifeworlds. Yet, despite curricula organised around vertical discourses such as science, geography and mathematics, the working classes, the poor and minority ethnic groups achieve less well in education than the middle classes. Bernstein's ground-breaking work revealed that working-class orientations to the world were different from middle class. Yet much of this early work on working-class knowledge 
remains underdeveloped and implicit in his definitions of horizontal discourse and knowledge structures.

The paper aims to re-think horizontal knowledge by paying attention to it as placebased, indigenous, historically developed forms of knowing in order: 1) to broaden debates about school knowledge; 2) to support teachers to recognise and legitimate forms of knowing beyond those prescribed by academic curricular and 3) to re-imagine it as living knowledge that has value.

To bring to light what more might be involved in non-vertical knowledge, the paper will provide i) case illustrations of such knowledge, ii) flesh out concepts such as affect, sensory and embodied ways of being to illuminate what might be powerful in horizontal knowledge and iii) will introduce concepts from Gilbert Simondon's work. Simondon's genetic ontology requires a shift in thinking from decontextualised, transcendental, fixed or dead categories, to knowledge made in the dynamic flow of life. To imagine horizontal knowledge as living knowledge requires a revaluing of context dependent, situated or profane knowledge, not as something that prevents people from gaining a critical awareness of their lives, but as that which keeps life going on. The next section provides brief case illustrations to introduce issues around horizontal knowledge.

\section{The school gate as a threshold}

Owain was aged 14 when we met him while undertaking longitudinal research in an excoal mining valley in south Wales ${ }^{1}$. He said that each day at the school gate:

You unplug the iplayer, take off your hoodie, roll down your sleeves so they can't see the tattoos and put on the tie..... As we're getting off the bus, they'll (the teachers) check we're wearing all our uniform and you haven't got earrings in and ... you have to hide everything before you get off the bus.

Owain felt the need to hide his recent tattoo representing the pride he felt in having a significant role in bringing up his baby cousin. He had already imagined himself as an adult, following in his father's footsteps in the building trade, and could envisage where on the estate he would build his own house. He told us he belonged to a close-knit family and had numerous relatives who lived within streets of one another. At school, others in his class told us that Owain had outgrown the institution, although his teachers told us he was doing well in the second to top class and was expected to get some good GCSEs (public examinations taken at aged 16 years in the UK). Owain explained that at the end of the school day, he took the bus home, changed clothes and travelled to the nearest town to hang out with friends from another school, "doing things we should not do".

Jac, also aged 14, said he found being at school very difficult. He had a complicated home background and when he found the pressure at school too challenging he absented himself and went to his aunt's place where she was building a house. He explained that if he did not regularly absent himself from school in the afternoons, he would not manage to attend school at all. He spoke with pride of his building-work and being able to drive a tractor.

Owain managed the transition between home and school life relatively smoothly albeit by undertaking rituals to hide elements that marked the grown-up status his family and 
friends extended to him. Jac had a different technique for coping with stress in school. He left lessons to practice the physical and skilled labour required to build a house.

We encountered many boys and girls in ex-coal mining towns who found school in varying degrees irrelevant, boring and stressful, yet expressed a deep sense of belonging to the place where they were growing up and all expressed a desire to achieve in life. We came to recognise that belonging to large family networks, being entrusted with responsible work such as bringing up children, caring for ill or disabled adults and building houses buttressed some of the more deadening experiences of schooling. When they spoke of experiences of developing skills such as riding motorbikes, mountain bikes and horses, or practising sports such as boxing, rugby, martial arts and dance they came alive. The ways of knowing and being that were valued in post-industrial places where we worked can be characterised as closely related to practices, context-embedded and local. This is the way Basil Bernstein, sociologist of education, characterised "horizontal discourse" (1996, p. 172). Yet, these ways of being that had to be left at the school gate. The next section argues that the split between horizontal and vertical knowledge is deeply rooted in Western cultures.

\section{Vertical and horizontal discourse}

Before re-thinking horizontal knowledge, it is worth briefly rehearsing what led to the typology of knowledge that enshrined the terms horizontal and vertical in current debates about curricula. Basil Bernstein developed a typology of knowledge in his later work $(1990,1996)$. There are some resonances between Bernstein's concepts of vertical and horizontal discourse and an anthropological distinction between the sacred and profane. Referring to Durkheim, Bernstein characterised the profane as the world of sensory representations and the scared as arbitrary conceptual relations that carry no necessity (1996, p. 169). In his later work, Bernstein referred less to knowledge as codes, in line with his earlier work on working and middle-class socio-linguistic codes, and adopted Foucault's concept of discourse to describe formal and everyday forms of knowledge. His typology runs from vertical to horizontal discourses, which broadly aligns with the anthropological concepts of sacred and profane, and abstract and concrete thinking.

Durkheim introduced the concepts of arbitrary and non-arbitrary to describe abstract and concrete thinking. In Western philosophy, arbitrary, or sacred knowledge, is associated with the pre-modern era dominated by religious thought, such that the only recognised form of knowledge belonged to God or gods and was made available to man [sic] through scared texts such as the Bible. Sacred knowledge was imagined to be fixed for all-time and so was transcendental. Other forms of knowing such as crafts of making, healing and commerce did not carry the status of sacred knowledge. Following the Enlightenment and the invention of the scientific method often associated with Francis Bacon, knowledge was imagined to grow according to hypotheses that were open to empirical disproof. In the modern era, knowledge was imagined to be created by scientists and represented as codes, concepts and principles, which could be disseminated widely through scholarly handbooks, journals and textbooks. Knowledge was no longer possessed by gods and fixed for all-time in a transcendental realm, and instead was open to discovery. Debates about the superiority of scientific knowledge in relation to other disciplines such as the humanities and social sciences have been ongoing and 
contentious, depicted as the science wars (see, e.g., Flyvbjerg, 2008, p. 1-13; Stengers, 2010, p. 1-13).

To some extent, Bernstein's typology of knowledge follows the modernist tradition of valuing scientific knowledge above all others. Within vertical discourse, he defines a range of types of knowledge according to their structure. He imagined the logic of a discipline as the conventions or rules according to which ideas can be aligned. Generally, Bernstein was thinking of the logics developed by academics in universities. He described the structure of scientific knowledge as explicit, coherent, systematically principled and hierarchically organised (Bernstein, 1996, p. 172).

The principle of the structuring of this knowledge moves the realizations towards more and more general propositions which integrate knowledge at lower levels and across an expanding range of apparently different phenomena. (Bernstein, 1996, p. 173)

Bernstein characterised the structure of social scientific knowledge as segmentally organised "as a series of expanding, non-translatable, specialized languages, with noncomparable principles of different, often opposed, assumption" (1996, p. 173). Horizontal knowledge progresses by "addition of another specialized language" (p. 173). Horizontal knowledge builds outward according to a logic of seriality adding or appropriating new territories.

In Bernstein's typology, horizontal discourse is not given the status of formal knowledge and refers to everyday or common-sense thinking described as:

... likely to be oral, local, context dependent and specific, tacit, multi-layered, and contradictory across but not within contexts ... the crucial feature is that it is segmentally organised. (Bernstein, 1999, p. 159)

Horizontal discourses share many features with horizontal knowledge structures in that they are context-specific and are "contradictory across but not within contexts" (1999, p. 159). I find resonances between horizontal discourse and Bernstein's earlier work on different social class orientations to the world, yet such connections remain implicit in his work. Before explicating what more might be considered as horizontal knowledge and discourse, the next section considers briefly how claims about the superiority of scientific knowledge.

To describe disciplinary or formal knowledge according to different structures or logics, as Bernstein does, is highly contentions and is widely debated in the field of Science and Technology Studies (STS). Scholars such as Bruno Latour and Donna Haraway argue that claiming scientific knowledge is more valid, more rational and more true than other forms of knowledge involves a carry-over from the pre-modern era when knowledge was imagined to be transcendental, as if it lies outside and above the human and natural worlds. While the general laws, principles and concepts developed within a specific field of science are highly useful within that disciplinary for understanding phenomena, once they are applied to other disciplinary fields or everyday life they do not necessarily work well.

Stengers (2010) cautions that the transcendent power attributed to abstract, scientific concepts translates them into seemingly immutable facts. In line with Latour, she points to how so-called "facts" developed in one area of science are taken up (or recontextualised to use Bernstein's term) in everyday discourse and become "factishes" (Stengers, 2010 , p. 19). She uses examples such as neutrinos, DNA, genes and innate intelligence (IQ). 
The vastness of the transcendental gets stuck to what might have started as a specific fact and over inflates it. She imagines factishes stalking the social world as monsters. We can only reduce these monsters to size by recognising that abstract generalisations are specific to the contexts where such phenomena were coaxed into view.

Scientists can be complicit in hiding the messy entanglements of social practices, discourse and technological instruments that create scientific facts (Haraway, 1991; Stengers, 2010). Stengers reveal the underbelly of science's so-called powerful knowledge and shows how it creates an overwhelming reality that distorts or hides other realities. In effect, concepts such as IQ become dominant discourses in Foucault's terms. Accordingly, scientific worlds and their monsters dominate us giving a sense that humans are impotent and stuck. To demonstrate how science dominates and occludes other ways of knowing, the next section takes a trip into the underground world of coal mining to make horizontal knowledge visible. It starts by painting a picture of how horizontal knowledge is entangled with place, geology, community life, corporeality and time.

\section{Knowledge in place}

Miners' knowledge can be characterised, arguably, as horizontal discourse or knowledge in Bernstein's typology (see Gamble, 2014). Coal mining communities grew up in specific places and developed forms of knowledge through the necessity to survive. The south Wales coalfields were formed millions of years ago when geological folds created by shifting tectonic plates, compressed coniferous matter deep underground. Today, mines involve a labyrinth of underground tunnels and caverns hewn out of rock. To become a miner required developing a specific kind of mentality, an embodied orientation to danger. I use these terms to hint of resonances with Bernstein's early work on workingclass orientations to meaning $(1973,1974)$. Unlike artisanal crafts associated with the preindustrial era, where tools and activities could travel, the technical ensemble of coal mining is profoundly rooted in the place where natural resources lie in specific geological formations (Simondon, 2017, p. 228).

Between the 1890s and 1920s, ex-mining valleys in south Wales grew from sparsely populated farming communities to globally important industrial centres within a relatively short time span. Mining communities expanded in landscapes of steep valleys above the coal seams. Coal was initially mined close to the surface using simple tools such as shovels, pickaxes and buckets. Up to the $1842 \mathrm{Act}$, whole families worked 12-14 hour shifts underground in cramped and dangerous conditions. The period of industrial mining saw mechanised lift cages drop groups of up to 50 men hundreds of metres below ground where they travelled along intricate corridors supported by pit props with ventilation systems and tracks on which trolleys laden with coal were pulled upward to the surface.

The decline of the mining industry in south Wales was steady yet slow from the 1930s to the present day. Then in the 1980s, the remaining mines were closed after violent confrontations between the police and community members who were trying to save their livelihoods. Today, in post-industrial times, mining places remain some of the most economically deprived and poorest in the UK (Ivinson et al., 2018; Social Mobility Commission, 2017). 
As part of our ongoing longitudinal work in the south Wales valleys, my students and I visited the National Museum for Wales. An ex-collier led us on an underground tour and explained the techniques of mining embellished with vivid personal stories of what used to happen underground. Below is an extract of the fieldnotes:

The tour involved a visceral, embodied, walking, stooping, encounter with rock, darkness and damp air. We had to lower our heads, to avoid banging them on the stone roof of tunnels that sloped into recesses where new coalfaces would have been hewn. Our hard hats were equipped with lamps that sliced through the utter, total darkness. We adopt reptilian-like body movements to feel our way. Persons, place, texture and matter created moving assemblages as we journey underground in what was an affective encounter, haunted with the past, present and (non) future of mining, laden with the heavy, on-going, mourning of the mine closures. Faced with an audience, the ex-collier bantered with us and told stories with pride of life underground. He gave us a sense of the chemistry of methane gasses and its dangers as it escaped from fissures in splitting rock. He sensitised us to the feel of rock, the smell of air and changes in temperature that can only be gained through long exposure to the place and having laboured with the tools of mining over time. Down here the collier came alive. The aliveness of the man entangled with the underground environment was in stark contrast to the depression, mental illness, and economic death of the community above ground.

The collier's knowledge has been formed by routines such as walking for miles underground before reaching the rock-face and of being enclosed with others, in close proximity in caged lifts. A split second could make the difference between being safe and in danger and so learning to attune to slight changes in the environment was crucial. A growing range of studies on embodied knowledge is providing useful concepts to illuminate the highly complex sensory and embodied sensibilities that miners acquire.

Studies in the field of social anthropology challenge notions of the body as bounded, rational and contained (Mellor \& Shilling, 1997). Ethnographic studies of sports such boxing (Bull, Gilroy, Howes, \& Kahn, 2006; Wacquant, 2004; Woodward, 2008), running (Allen-Collinson \& Owton, 2015) and dancing (Potter, 2008) describe the trans-boundary capacities of heat, touch and smell, which blur the separation of bodies and environments. For example, athletes undertake warming-up exercised to elongate their muscles develop a heightened experience of heat as a perception that is felt within the body and yet relates to the external environment (Potter, 2008). Warming up involves both physical and psychological sensations as people feel an increase in energy. Touch, a sense that has low status in Western cultures, is said to be the least mediated by cognition (Classen, 1993; Moulton, 2010). In effect, Western cultures have a restricted range of concepts to describe touch. Yet, we only have to watch a blind person exploring artefacts in a museum through touch to realise the human potential to develop tactile sensibilities. The value given to sensory knowledge varies across cultures and eras. For example, in Latin American, the Mayan and Tzotzil people recognise heat as a basic force of the universe and have a highly elaborated thermal symbolism. For them, heat is symbolically related to the life cycle and is central to rituals of marriage and baptism (Allen-Collinson \& Owton, 2015). Sensations such as heat and touch emerge within a self-body-society nexus (AllenCollinson \& Owton, 2015). I want to make a link between cultural variations in how different sensory registers are more or less elaborated and the development of sensory affordances within mining communities. We can extend the self-body-society nexus to 
include place and in the case of mining, place involves a specific geological, dynamic underground environment.

Mining communities have developed highly elaborated, multi-sensorial attunements to the underground environment so they could detect the slightest change in the atmosphere driven by the need to stay safe. For example, the ability to detect a specific sound, such as the popping of wood, enables them to anticipate the imminent collapse of a pit prop (Sauer, 1998). This heightened awareness allows miners to detect extremely slight differences in sound, touch, smell or feel. Miners refer to this sixth sense as pit sense (Sauer, 1998). Pit sense develops over the time, is specific to place and it transmitted though bodily practice passed on by groups of mines.

Simondon (2017) described miners' embodied knowledge as taking place in union with nature where boundaries between bodies-environment-intuition are folded in a Deleuzian sense. Before pursuing theories that overcome boundaries between bodiesenvironments-place-culture in more detail, there is one last point to make with regards to Elizabeth Sauer's study.

Sauer's study examined accident reports in the mining industry. Miners were interviewed following accidents as part of the process of reviewing safety. The technical editors of the safety manuals describe risk using scientific categorise such as "load", "pressure" and "compression" from disciplines such as physics, geology and chemistry. Even when miners explained in their terms how accidents took place their accounts did not make it into the safety manuals. By using scientific concepts that are detached, decontextualised and generalised, miners' complex, multi-sensorial, embodied knowledge, pit sense was erased. The manuals erase horizontal knowledge and in this case, scientific knowledge looks more like superior arrogance that dismisses the difference between theory and practice (Stengers, 2010, p. 3). The next section returns to stories about the origins of ideas about knowledge such as those that inspired Bernstein's typology of knowledge to introduce the work of Gilbert Simondon.

\section{From knowing to being}

In rethink horizontal knowledge, Simondon's (2017) genetic ontology provides a useful alternative account that focuses on the development of technical objects across time. I refer again to mining to introduce concepts such as the collective transindividual.

Miners share a uniquely collective form of knowing in which humans and nature are fused or folded. The popping sound created when a wooden pit prop cracks is detected intuitively in a microsecond as a feeling that something is not right. Pit sense is transmitted across generations of miners. To remain safe, miners induct newcomers into become open and hyper-attentive to the sounds, smells, feel and touch of the underground environment and distil in them a sense of collective responsibility, because each miner depends absolutely on others for their safety. We might imagine the underground as a liminal space (Hughes, 2014) where miners are saturated by nature through a multisensorial, immersive awareness. This beingness comes from miners working as a connected organism sensing together as they inhabit the underground world; something akin to a blind animal sensing and feeling as it burrows within the earth. In effect, the thinking takes place in a living environment, where the inner and exterior worlds are merged. In a Deleuze (1993) sense, the inside is folded onto the outside, as environment. 
To capture this sense of unity between humans and nature, Simondon invokes a collective transindividual world (Combes, 2013; Hughes, 2014).

Pit sense is not a cognitive knowing. This kind of embodied knowing surpasses or is more than individual cognition. Muriel Combes writing about Simondon calls this "the intimacy of the commons" (2013, p. 40). If such thinking does not belong inside a human mind, then where does it take place? The answer according to Simondon requires some quite radical rethinking of the bounded, rational subject that Western philosophy inherited from Descartes.

Simondon, along with other post-human, and new materialist thinkers such as Rosi Braidotti, Gilles Deleuze and Felix Guattari look back to the seventieth century philosopher, Baruch Spinoza, who argued against Descartes' separation of subjectivityenvironment, God-nature and mind-body. Simondon argued that God and Nature were different names for the same thing. This alternative story recognises forms of knowing, such as pit sense as feelings that arise in the dynamic flow of life. Feelings are registered before sensation becomes rational, conscious thought. Yet in a more radical vein, Simondon elevates such pre-conscious, embodied thinking to a high status, indeed it supplants transcendental knowledge. He follows Spinoza to suggest that what unites people and enables the social organisation to emerge is not arbitrary or transcendent concepts that are discursive, detached and consensus dependent but natural, or pertaining to nature. Specifically, he argues that what humans share, they share through their belonging to a common nature. In a way, Spinoza places Descartes' God in nature. In effect, he grounds the origins of social life in nature, and thus in the "real". The next section presents Simondon's alternative story of the history of ideas.

\section{Collective individuation}

Simondon (2017) starts with the in-between, not with knowledge or subjects but with the development of technical objects across eras. For him, life emerges with technology and technical objects such as the pickaxe, the internal combustion engine and, in contemporary times, magnetic resonance imaging (MRI). Simondon rejects the subject-object division that imagined a unified and autonomous Cartesian subject as the centre of knowledge. He insists that human beings are not defined according to "essences" that lie either in an interior, such as the psyche imagined by Freud, or in the exterior such as social organisations described by Marx and Durkheim (Barthélémy, 2012, p. 205). He emphasises how the invention of technical objects set up processes that generated splits between a once unified plane that humans shared with nature. Accordingly, "psychological individuation does not pre-exist, ready made" (Combes, 2013, p. 39) as a condition from which collective life emerges. Simondon starts the other way round; for him, collective life is part of nature and comes before subjectivity. As Joe Hughes suggests:

both the psychic and the collective are co-produced through the "elaboration" of the transindividual, a process of individuation which cuts across individuals, putting them in relation to one another on the basis of their preindividual realities (Hughes, 2014, npn).

Simondon describes four temporal phases and each creates a different split between humans and the world. The way to imagine this is that successive splits followed from the development of increasingly sophisticated technical objects, yet not only is the human 
split from some imagined external world; these splits create new worlds, or regimes and new ways of orienting to them, which in turn create new forms of individuation. The first phase is characterised by a union between nature and humans. Here the human is characterised as pre-individual, and what connects humans is their pre-human nature (Hughes, 2014 citing Combes, 2013, p. 48). In this regime, the human is fundamentally a collective being, a transindividual.

As Hughes (2014) points out, Simondon's notion of the transindividual starts from a tension. We need to imagine the subject made up of two unequal parts, the individual and what the pre-individual shares with nature.

Insofar as the subject's preindividual share always exceeds the limits of the individual, the relationship between the two parts is in a state of permanent tension. The tension between these two levels is experienced as affectivity, an internal relation to the outside (Simondon ILFI 252, cited in Hughes, 2014).

What humans share with nature will always exceed who they can become as persons. The tension is experienced below the level of conscious awareness as affect. To become a person, or to become individuated cannot be achieved on one's own; it requires a collective. No person can achieve full psychic stability on their own, it has to join with what "surpasses it while accompanying it" (Combes, 2013, p. 40). In a simplified form, affect becomes perceived as emotion in the process of resolving the tension and provides a driving force to become a person, to survive, and to live in the intimacy of the commons.

The early phase is characterised by a magical unity between man [sic] and the world (Simondon, 2017, p. 177). In this pre-historical (primitive) phase humans share nonconscious intelligence with animals and other beings through processes of phylogenesis (e.g., Wilson, 2015). In this era, structures in the universe are given by movement and place (Simondon, 2017, p. 178). Without structure, there would be continuous time and space. Structures are key-places that keep hold of the forces contained in the ground (fond) of reality that supports them. Such places might be enclosures or passages, and sacred places such as elevated peaks occupied by, for example, the lord of the mountain (p. 178). Simondon suggests they "localize and focalize the attitudes of the living vis $a$ vis its milieu" (p. 178).

I wish to suggest that mines are physical places that hold the forces contained in the ground. I suspect this is why when the unemployed miners looked back to their mining days, they spoke of those times with extraordinary levels of satisfaction and many told us they were the best days of their lives, despite the dangers. They always spoke of the camaraderie experienced with others underground. Underground they were in a collective unity with others and with living nature. They spoke with a unique kind of pride about mining work and we had the impression that they worked in unison as a collective organism, highly attuned to the liveliness of nature. In this way, they were in touch with that which surpasses individuation while accompanying it. They merged with nature while accompanying it. For Simondon, the transindividual is where the individual relates to him or herself in the very act of relating to others and here we can add a further form of relating; that of relating also to the ongoing life of nature.

The three phases outlined by Simondon correspond to different versions of subjectivity. The term individuation is used to emphasise movement and becoming rather than a fixed, unified subject. The first split separated man [sic] from a (primitive) magical world 
where he [sic] was unified with nature. This split, instigated by the invention of technical tools, spawned the world, or regime, of religion imagined above and a world of technics below, as two sides of the same coin. For Simondon, regimes have theoretical and practical modes. The second split created the regimes of science and ethics. Science grew into domains of knowledge such as physics, chemistry and geology. The first phase created pre-individuation and the second phase created vital individuation, followed by psychic individuation, which is a transitory phase and finally the psycho-social individuation of post-modernity. We can imagine these are different orientations to meanings and different kinds of worldings.

Yet, the important point for this paper is that there is a continuous and ongoing rationality between forms of being associated with phases.

A being, considered as individuated, can in fact exist according to several phases that are present at the same time, and it can change phases in itself; there is a plurality in being that is not the plurality of parts. (Barthélémy, 2012, p. 226).

We might say that vestiges of each phase's forms of thought continue to be alive and available as parts of the culture in technical objects and become present again in moments of creative change. The colliers' pit sense mentioned above, is an instinctive, or vital knowing that only develops when experiences of successive generations create the conditions of perception, and the essential mental structures to adapt to the milieu (Simondon, 2017). A heightened awareness of sound, smell and imminent danger come from a long legacy of mining practice passed on through generations working in a specific underground milieu. When the mines closed, losing their jobs gave the miners a new individuation of unemployment. This split between having a social purpose and becoming "a drain on society" and worthless was imposed by the logic of capitalism. Capitalism split the men from their milieu. My story of going underground suggests that some men have at least two subjectivities - above and below ground, and they move between them within the same day. Accordingly past, present and future do not follow sequential linearity but are folded into contexts and practices.

Simondon's account helps us to imagine that instead of one form of knowledge overturning another, humans come into being through a plurality of connections with a multiplicity of worlds, and $a$ world is not there once and for all. The concept of milieu helps to capture the dynamic movement of life with human beingness and enables us to recognise instinct, intuition, and practical forms of knowing related to the eras of magic, religion and science co-existing, yet having different origins. Pre-individuation becomes individuated according to the milieu or ensemble through which it finds life and expression. Accordingly, there is no individuation without milieu.

In the earlier example, Owain came into being different in the contexts of school, home, and with his peer or among relatives. Accordingly, a human being is not motivated to know, so much as to live or survive. Knowledge is always directed at problems thrown up by the life course as lived. By placing living necessity before knowledge, we can hear young people's pleas that school is boring and irrelevant in a different way. The need to know comes from the milieu in which they are living as when Jac learns to drive a tractor to help with his aunt's building work. 


\section{Movements in place}

As young people appropriate corporeal activities in mining communities they invent, transform and recast practices passed down from older generations. These corporeal practices and movements include features that mimetically resonate with past practices of mining and farming such as being outdoors, being physically active, developing skills and gaining muscle strength. Riding motor bikes (Ivinson, 2014a) and helping to build a house mimetically reference and point to rituals of the past reactivated in the present that potentially change and create something new for all participants (Wulf, 2011). These activities are not a straightforward reproduction of past practices; they include conflicts, struggles and tensions. Skilled bodily performances are shaped by contemporary expression of power relations and by virtual media that at the same time accept and question a given social order.

Mining is one example of a specialist physical activity. Trades such as groundwork, plastering, and plumbing also involve corporeal dexterities that are entangled with technical knowledge in specific ways. Young peoples' activities such as building and motor-biking are shaped by past techniques to create altogether new co-compositions involving place, techniques, terrain and social bonds. These micro-worldings resonate with a kind of known-unknown of the past reverberating in the present.

When the miner acts instinctively to sense danger, he is acting according to a motivation to survive. It is a feeling generated in the event; a force that propels being; a non-human impersonal intuition to survive, like a flower bending towards the light of the sun. It is this impersonal force that is the basis of true collective action according to Simondon. It is the feeling of solidarity that kept the miners alive and that might, if given half a chance, re-generate post-industrial communities.

Groups connected to places, landscape and local contexts where specific practices have developed over time, have different sensitivities and perceptual registers to those living in urban towns, for example. We are in danger of losing these visceral, embodied, socially situated ways of knowing if we fail to value, recognise and encourage them.

\section{Implication for education}

Another educational theorist with an interested in what humans share with nature is Lev Vygotsky. In his work, the natural line of development or phylogenetic line relates to what humans share with upper primates. Educationalists tend to focus on Vygotsky's cultural line and its importance for the development of higher forms of mental functioning (e.g., Wertsch, 1985, p. 48) while ignoring the natural line of development. According to Vygotsky, what makes humans different to animals is the zone of proximal development (ZDP) where the natural line of development referred to as intrapsychic crosses the cultural or interpsychic line. The ZDP is a "dynamic region of sensitivity in which the transition from intrapsychological to interpsychological functioning can be made" (Wertsch, 1985, p. 67). The reason why Vygotsky developed the ZDP was because it points, not to the mental function a child already has but to what the child can potentially become. Vygotsky's developmental psychology is more in accord with Spinoza's dynamic subjectification than Descartes' notion of the bounded subject (Ivinson 2012, 159). The ZDP creates a new interdependency between the self and the other and, and as 
Padadopoulos (2011) suggests this is Vygotsky's equivalent of the liminal space where processes of individuation take place.

Simondon's work enables us to expand Vygotsky's notion of the ZDP. Most often educationalists recognise the interpsychological line of development as the cultural line made available to novices through teachers and other experts with the support of mediating tools. Language is the primary cultural tool in Vygotsky's work. Simondon provides a story about the development of technical objects or tools and so elaborates further relations between culture and nature and so between the intra (mental), and interpsychic (cultural) lines of development.

Simondon enables us to imagine culture not as a single line, so much as multiple, made up of the sediment layers created by the development of technical objects relating to the magical, religious and scientific eras. As a child comes in contact with different kinds of cultural tools, she becomes oriented to meanings, at times as vital, psychic and psychosocial individuations. Becoming, then, can be imagined as multiple processes of individuation involving a plurality of relationships with tools, others, nature and landscapes within milieux, such as home, community and school.

When thinking about dynamic subjectification, we can think of processes of becoming through play, intergenerational activities specific to place and schooling. Play allows a child to be fully, intensely, immersed or fused with ongoing life. Deleuze \& Guattari, (1987/2014, p. 179) associate this with jouissance and vital individuation. Maybe when taking part in physical and technical activities, such as playing a sport or riding motorbikes, becoming involves psychic individuation. In the mining communities of south Wales, these kinds of activities share some of the miners' transindividuation where bodyself-other-place are folded. Young people's activities reverberate with indigenous ways of knowing that are still part of the ongoing ways of knowing and surviving in communities. Maybe when taking part in subject lessons, becoming involves psycho-social individuations and involves making meaning oriented through the guiding principles of disciplinary logics within ecologies (Stengers, 2010) of formal discourses, such as science and art.

Some implications are: i) there are diverse tools associated with pre-history, the religious and the scientific regimes, ii) these are still available today, iii) each enables humans to make connections and become in different ways, and so inhabit different regimes or worlds where the rules of engagement are specific to that ecology. Thus we, and the children and young people we teach, have a multiplicity of ways of being, relating and knowing. Simondon's work has wide implications for re-thinking learning and expanding the imaginative purview of intra-actions (Barad, 2007) between knowing and worlding.

We can recognise that Owain and Jac become different as they enter the school gate, a building site and their family homes and that each milieu affords them an ongoing sense of becoming. If we can imagine a multiplicity of pre-individuations as young people strive to survive, belong and develop a personality, then we can start to value and acknowledge their diverse lifeworlds. Education involves opening up evermore lifeworlds such as those of science, geography, art and sport, without denying that some regimes enable some young people to become a person more than others. Re-thinking horizontal knowledge will enable some young people to become more; more than social class, more than poverty, more than an exam failure and more that an individual, fixed for all time. It enables us to imagine education bringing young people into a multiplicity of worlds and so to encounter the excesses that we humans share in common, with nature and with 
others. The beautiful risk for educators presented in this paper is to think beyond the unified, autonomous Cartesian subject as the centre of knowledge and to work with and not against the power of living knowledge.

\section{Note}

1. The paper draws on a succession of studies conducted between 2006 and 2018 in the exmining and steel producing valleys of south Wales. Three studies were conducted in schools and communities in south Wales ex-mining valley communities: (1) on young people's understandings of skill in the Llynfil Valley in primary and secondary schools between 2006-2010; (2) on young people's understandings of place, in schools and communities in the Cynon Valley, called the Young People and Place (PI Ivinson) project between 2010-2013, and (3) on young people's sense of wellbeing in schools and communities in the Taff Valley between 2013-2018 as part of Productive Margins: Regulating for Engagement project, and was called Making, Mapping and Mobilising in Merthyr.

\section{Acknowledgments}

I would like to thank the editors of the special issue for their high level of engagement with this paper as it evolved and two anonymous reviews for invaluable insights and intellectual guidance.

\section{Funding}

This work was supported by the Economic and Social Research Council [ES/K002716/1] and RES-57625-0021 (ESRC/HEWFCW).

\section{Notes on contributor}

Gabrielle Ivinson develops arts-based methods to attune to what lies beyond the spoken word, enabling embodied, affective dimensions of difficult issue such as poverty to be recognised.

\section{ORCID}

Gabrielle Ivinson (D) http://orcid.org/0000-0002-5552-9601

\section{Ethics statement}

All studies had ethical approval from the relevant university ethics committees, and all participants gave consent.

The paper draws on a succession of studies conducted between 2006 and 2018 in the ex-mining and steel producing valleys of south Wales. (1) on young people's understandings of skill in the Llynfil Valley in primary and secondary schools between 2006-2010; (2) on young people's understandings of place, in schools and communities in the Cynon Valley, called the Young People and Place (PI Ivinson) project between 2010-2013, and (3) on young people's sense of wellbeing in schools and communities in the Taff Valley between 2013-2018 as part of Productive Margins: Regulating for Engagement project, and was called Making, Mapping and Mobilising in Merthyr. 


\section{References}

Allen-Collinson, J., \& Owton, H. (2015). Intense embodiment: senses of heat in women's running and boxing. Body \& Society, 21(2), 245-268. doi:10.1177/1357034X14538849

Barad, K. (2007). Meeting the universe halfway: Quantum physics and the entanglement of matter and meaning. Durham and London: Duke University Press.

Barthélémy, J.-H. 2012. Glossary. Fifty key terms in the works of Gilbert Simondon. (Arne De Boever, (trans.)). In A. De Boever, A. Murray, J. Roffe, \& A. Woodward (Eds.), pp. 203-231. Being and technology. Edinburgh: Edinburgh University Press.

Bernstein, B. (Ed.). (1973). Class, codes and control 2, Applied studies towards a sociology of language (Second (revised) ed.). London: Routledge.

Bernstein, B. (1974). Class, codes and control 1, Theoretical studies towards a sociology of language (Second (revised) ed.). London: Routledge.

Bernstein, B. (1990). The structuring of pedagogic discourse. London and New York: Routledge.

Bernstein, B. (1996). Pedagogy, symbolic control and identity: Theory, research, critique. London and Bristol: Taylor and Francis.

Bernstein, B. (1999). Vertical and horizontal discourse: An essay. British Journal of Sociology of Education, 20(2), 157-173.

Bull, M., Gilroy, P., Howes, D., \& Kahn, D. (2006). Introducing sensory studies. Senses \& Society, 1(1), 5-8.

Classen, C. (1993). Worlds of sense: Exploring the senses in history and across cultures. London: Routledge.

Combes, M. (2013). Gilbert Simondon and the philosophy of the transindividual. Cambridge: MIT Press.

Deleuze, G. (1993). The fold: Leibniz and the Baroque. (T. Conley, Foreword and Trans.). London: Athlone Press.

Deleuze, G., \& Guattari, F. A. (1987/2014). Thousand plateaus. London and New York: Bloomsbury.

Flyvbjerg, B. (2008). Making social science matter: Why social inquiry fails and how it can succeed. Cambridge: Cambridge University Press.

Gamble, J. (2014). 'Approaching the sacred': Directionality in the relation between curriculum and knowledge structure. British Journal of Sociology of Education, 35(1), 56-72.

Haraway, D. (1991). Simians, cyborgs and women: The reinvention of nature. London: Free Association Press.

Hughes, J. (2014). The intimacy of the common: Gilbert Simondon today. Theory and Event, 17(2). Project MUSE muse.jhu.edu/article/546472

Ivinson, G. (2012). Boys, skills and class: Educational failure or community survival? Insights from Vygotsky and Bernstein. In H. Daniels (Ed.), Vygotsky and Sociology, pp. 155-174. London and New York: Routledge.

Ivinson, G. (2014a). Skills in motion: Boys' motor biking activities as transitions into working class masculinity. Sport, Education and Society, 19, 605-620.

Ivinson, G., \& Renold, E. (2018). Writing as bodywork: Poverty, literacy and unspoken pain in exmining south Wales valleys communities. In R. Hattam, S. Gannon, \& W. Sawyer (Eds.), Resisting educational inequality: Reframing policy and practice in schools serving vulnerable communities, pp. 227-293. London and New York: Routledge.

Ivinson, G., \& Renold, E. (2013a). Subjectivity, affect and place: Thinking with Deleuze and Guattari's body without organs to explore a young teen girl's becomings in a post-industrial locale. Subjectivity, 6(4), 369-390.

Ivinson, G., \& Renold, E. (2013b). Valleys' girls: Re-theorising bodies and agency in a semi-rural, postindustrial locale [Special issue: Feminist materialisms and education]. Gender and Education, 25(6), 704-721.

Ivinson, G., Thompson, I., Beckett, L., Egan, D., Leitch, R., \& McKinney, S. (2018). Learning the price of poverty across the UK. Policy Futures in Education, 16(2), 130-143. doi:10.1177/1478210317736224

Mellor, P., \& Shilling, C. (1997). Re-forming the body. London: Sage.

Moulton, I. F. (2010). In praise of touch: Mario Equicola and the nature of love. Senses \& Society, 5(1), 119-130. 
Padadopoulos, D. (2011). In the ruins of representation: Identity, individuality, subjectification. British Journal of Social Psychology, 47(1), 139-165.

Potter, C. (2008). Sense of motion, senses of self: Becoming a dancer. Ethnos, 73(4), 444-465.

Renold, E., \& Ivinson, G. (2014). Horse-girl assemblages: Towards a post-human cartography of girls' desires in an ex-mining valleys community. Discourse, 35(3), 361-376.

Sauer, B. (1998). Embodied knowledge: The textual representation of embodied sensory information in a dynamic and uncertain material environment. Written Communication, 15(2), 131-169.

Simondon, G. (2017). On the existence of technical objects. (C. Malaspina \& J. Rogove, Trans.). Minneapolis and London: A Univocal Book, Minnesota Press.

Social Mobility Commission. (2017). State of the nation 2017: Social mobility in Great Britain. Retrieved from https://www.gov.uk/government/publications/state-of-the-nation-2017

Stengers, I. (2010). Cosmopolitics I. (R. Bononno, trans.). Minneapolis: Minnesota Press.

Thomas, G., Elliott, E., Exley, E., Ivinson, G., \& Renold, E. (2018). Light, connectivity and place: Young people living in a post-industrial town. Cultural Geographies, 25(4), 537-551.

Wacquant, L. (2004). Body and soul: Notebooks of an apprentice boxer. Oxford: Oxford University Press.

Wertsch, J. V. (1985). Vygotsky and the social formation of mind. Cambridge, MA: Harvard University Press. Wilson, E. A. (2015). Gut feminism. Durham and London: Duke University Press.

Woodward, K. (2008). Hanging out and hanging about: Insider/outsider research in the sport of boxing. Ethnography, 9(4), 536-560.

Wulf, C. (2011). Mimesis in early childhood: Enculturation, practical knowledge and performability. In M. Kontopodis, C. Wulf, \& B. Fichtner (Eds.), Children, development and education: Cultural, historical and anthropological perspectives (pp. 89-102). New York: Springer.

Young, M., \& Muller, J. (2013). On the powers of powerful knowledge. Review of Education, 1(3), $229-250$. 